\title{
The Theory of Recognition in the Frankfurt School
}

Timo Jütten, University of Essex

\section{Introduction}

The theory of recognition is a paradigm shift in Frankfurt School critical theory. It builds on Habermas' earlier shift from what he called a "philosophy of consciousness" to an intersubjective grounding of social criticism, but it departs from Habermas' theories of communicative action and discourse ethics. Instead, it focuses on recognition relations that go beyond linguistically mediated communication to encompass affective attitudes, and on a dynamic conception of social struggles for recognition that makes sense of historical social struggles for equal rights and the recognition of marginalized contributions to socially shared goals. Looking forward, the theory of recognition helps critical theorists to evaluate "recognition orders" and to criticize social developments that fail to institutionalize recognitive relations that enable individual self-realisation.

Needless to say, this is an ambitious project that depends on philosophical and empirical premises which can be contested, and on the articulation and defense of a complex philosophical vocabulary which is in need of clarification and extension. In this chapter I aim to offer an initial overview of the theory of recognition in the Frankfurt School tradition. I also discuss its sources and some conceptual questions that have been raised in the secondary literature. Then I turn to the aspect of Honneth's theory that has received most attention, his account of the emergence of modern capitalism as a recognition order. I close with some remarks about future directions of research. 
The theory of recognition first appears in Axel Honneth's book, The Struggle for Recognition (1996 [1992]). Since then, Honneth has clarified his intentions and extended the scope of his theory in many publications, including his exchange with Nancy Fraser, Redistribution or Recognition? (Fraser and Honneth 2003), in which he introduces a number of important new concepts that extend the explanatory power of recognition. Most recently, Honneth has reconceived his project as a theory of social freedom. However, his extensive analysis of the development of social freedom in Freedom's Right (2014 [2011]) still relies on the concept of recognition developed in his earlier work. Thus, the basic structure of recognition has remained unchanged.

\section{Honneth's Theory of Recognition: A Bird's-Eye View}

Honneth defends a "formal conception of ethical life" and derives the normative standards for social criticism from it (Honneth 1996: Ch. 9; Honneth 2003b: Sec. III). He arrives at his conception of ethical life through a phenomenology of historical struggles for recognition and against disrespect and humiliation. This phenomenology is informed by the social-theoretical conviction that "the reproduction of social life is governed by the imperative of mutual recognition" (Honneth 1996: 92). According to this phenomenology, the negative experience of disrespect and humiliation motivates struggles for recognition in which social groups stake their claims for the recognition of hitherto unrecognized or undervalued aspects of their members' personalities, rights or contributions to social reproduction.

This phenomenological analysis gives rise to a complex typology of recognition, which can be organized according to the dimension of personhood to which a particular mode of recognition is addressed, to the forms of recognition that are adequate to the particular dimension of personhood and to the social spheres in which the particular forms of recognition 
have been historically institutionalized (Honneth 1996: 129; Honneth 2003a: 138-44). Thus, according to Honneth, subjects must be recognized in their singularity as possessors of needs and emotions, as autonomous agents with moral responsibility, and as possessors of particular traits and abilities that enable them to contribute to social cooperation (Ikäheimo 2002). The forms of recognition adequate to these dimensions of personhood are love (or friendship), respect and social esteem. And, historically speaking, modern capitalist societies have institutionalized these forms of recognition in the bourgeois family, the various legal and political institutions guaranteeing equality before the law and in the industrially organized division of labour respectively.

To be sure, the historical institutionalization of these forms of recognition has been imperfect. In particular, the "achievement principle" (Honneth 2003a: 143) that provides the normative standard for the distribution of social esteem in modern capitalist societies embodies the ideological self-understanding of the "independent, middle-class, male bourgeois" (Honneth 2003a: 141), whose economic activity as an entrepreneur or professional becomes identified with individual achievement per se, while the specific achievements of dependent working-class labourers and women performing household work or raising children have only come to be recognized "with many class- and gender-specific delays" (Honneth 2003a: 142). But the decisive claim of the recognition-theoretical view is that in modern capitalist societies the principles of affective care, equal treatment and individual achievement provide the normative framework against which subjects judge the legitimacy of their social and political institutions as well as any existing social inequality (Honneth 2003a: 148-49).

At this stage in the argument Honneth shifts perspective from a social theory of recognition relations to a normative theory of social justice. He argues that "[b]ecause we live in a social 
order in which individuals owe the possibility of an intact identity to affective care, equality and social esteem, it seems...appropriate, in the name of individual autonomy, to make the three corresponding recognition principles the normative core of a conception of social justice" (Honneth 2003a: 181-82). In other words, mutual recognition in the three dimensions of personhood is a condition of possibility for individual autonomy, and, therefore, for selfrealization, because the development of a positive self-relationship, including the development of self-confidence, self-respect and self-esteem, depends upon this recognition (Honneth 1996: 173-74). Taken together, these requirements specify Honneth's formal conception of the good life, because mutual recognition "provide[s] the intersubjective protection that safeguards the conditions for external and internal freedom, upon which the process of articulating and realizing individual life-goals without coercion depends" (Honneth 1996: 174).

Moreover, the application of these principles of justice is future-directed: the social justice obtaining in a society is proportionate to the moral quality of the social relations of recognition. Here, Honneth offers two criteria for progress in the relations of recognition. Social recognition increases through individualization and inclusion, where individualization means that individuals gain social recognition for more aspects of their personalities, and inclusion means that more individuals are fully recognized in society (Honneth 2003a: 184-86). Underlying this conception of moral progress is the idea that the principles of recognition possess a "surplus of validity" (Honneth 2003a: 186) that transcends their current employment and that can be appealed to in struggles for recognition. This is particularly clear in the sphere of modern law, where the scope of equality has broadened significantly over the last few decades, but it is less clear where the spheres of love and social esteem are concerned. However, Honneth suggests that the overcoming of stereotypes and the extension of the category of esteemed activity 
beyond the traditional conception of "gainful employment" may be examples of moral progress in these spheres (Honneth 2003a: 188).

Taken together, Honneth's critical theory of recognition offers two normative criteria for the evaluation of social institutions and practices. On the one hand, his formal conception of ethical life specifies the intersubjective preconditions of individual autonomy and selfrealization that must be protected in any modern democratic state. On the other hand, his conception of moral progress through increasing individualization and inclusion enables Honneth to reconstruct the rationality of historical struggles for recognition, and to diagnose social potentials for further individualization and inclusion, which will afford more individuals the opportunity to live flourishing ethical lives, as well as the structural impediments that prevent them from happening.

In Freedom's Right Honneth offers a third criterion of evaluation: social institutions and practices will be legitimate in the eyes of modern subjects to the extent that they enable them to realize their social freedom, that is, a form of freedom in which individuals complement and complete each other. Social freedom requires that the social institutions in which people act are free in the sense that they enable people to realize their freedom in cooperation with others who share their aims. Rather than a departure from recognition, it is a form of it. As Honneth puts it, social freedom can be understood as "the reciprocal experience of seeing ourselves confirmed in the desires and aims of the other, because the other's existence represents a condition for fulfilling our own desires and aims" (Honneth 2014: 44-45), and that is a relationship of mutual recognition. 


\section{Sources of the Theory of Recognition}

The theory of recognition has its philosophical roots in the Hegel. In The Struggle for Recognition Honneth argues that Hegel's original idea in his earliest work combines an intersubjectivist conception of human identity with the distinction of various media of recognition (love, law, solidarity), and a historically productive role for moral struggles for intersubjective recognition (Honneth 1996: 63). While Honneth had argued originally that these insights are occluded in Hegel's work from the Phenomenology of Spirit (1807) onwards and never occupy a systematic role in his philosophy again, in his more recent work Honneth finds a systematic place for recognition even in Hegel's later work (Honneth 2010a). This motivates his re-actualization of Hegel's Philosophy of Right (1821) in Freedom's Right, where Honneth explicitly defends Hegel's distinction of three spheres of social recognition, although he specifies these spheres differently, giving much greater weight than Hegel to deliberative will formation in a democratic public sphere.

In addition to these philosophical roots, Honneth's theory of recognition also is based on insights from social psychology, psychoanalysis, and developmental psychology. Like Habermas, in The Struggle for Recognition Honneth draws on George Herbert Mead in order to show that individuation occurs through socialization, but he focuses on the mutual attribution of recognitive status. Likewise, he draws on the psychoanalyst Donald Winnicott in order to demonstrate that the strong affective relationship between young infants and their carers is best understood as a relationship of mutual recognition which enables the infant to develop a sense of itself and its needs. More recently, Honneth also has drawn on the developmental psychology of Michael Tomasello in order bolster his argument about the primacy of intersubjectivity (Honneth 2005). 
Finally, since The Struggle for Recognition aims to elucidate "the moral grammar of social conflicts" (so its subtitle), Honneth also uses historical studies that explicate the moral selfunderstanding of individuals and collectives that engaged in various social struggles. For example, he finds support for his arguments in the works of the English social historian E.P. Thompson and the American political scientist Barrington Moore. Thompson had shown that social resistance to capitalist modernization often is the response to the disappointment of moral expectations based on a tacit social contract between classes, rather than a spontaneous reaction to deprivation or hardship. Moore had built on these insights and demonstrated that the moral injury experienced by members of activist groups in social uprisings often was one of disrespect, based on the breakdown of a traditional system of mutual recognition and a consequent loss of self-worth (Honneth 1996: 166-67). These historical studies have remained central to Honneth's understanding of recognition struggles throughout his work, as he has generalized their conclusions and used them to illustrate more recent struggles (Honneth 2003a: 131; see also Honneth 2014: 208-10).

\section{Conceptual Questions}

Clearly, a critical theory as ambitious and eclectic as this is open to a number of critical questions. Here are three common ones. To begin with, one may ask whether Honneth's reliance on a conception of ethical life, albeit a formal one, commits him to a philosophical anthropology that will open him up to criticism from those who eschew such commitments (Zurn 2000:115-24). In response, Honneth clearly remains committed to philosophical anthropology as a foundation for critical theory (Honneth 2007a, 2008). However, his formal conception of ethical life is grounded in a weak philosophical anthropology. While the need for mutual recognition is an "anthropological constant" (Honneth 2003a: 174), the concrete 
forms of recognition that are necessary for the achievement of self-realization change over time and are therefore historically specific (Honneth 2003a: 181).

As we have seen, the theory of recognition is based on insights from social psychology, psychoanalysis, and developmental psychology. This may allay some worries about Honneth's commitments to philosophical anthropology, but the use of these empirical insights does raise difficulties of its own. In particular, critics have suggested that Honneth's use of Winnicott's object-relations account of infant development, which enables him to conceptualize the relationship between the infant and its primary caregiver as a form of mutual recognition based on unconditional love, downplays the conflictual elements of this relationship in favor of a mutualistic one (for an excellent discussion of these issues see Petherbridge 2013: Ch. 9).

Another important question is whether recognition should be understood on the model of attribution or perception (Ikäheimo 2002; Laitinen 2002). Thus, according to Honneth, the second form of recognition is respect for autonomous agency and moral responsibility. But it is not immediately clear whether a recognitive attitude of respect toward a person attributes autonomous agency and moral responsibility to the person, or whether it perceives that the person is an autonomous agent with moral responsibility and responds accordingly. On the face of it, both of these alternatives have their problems. If recognition attributes moral status to people, we lack an internal criterion for the attribution of positive qualities to a subject. Recognition may seem arbitrary, rather than responsive to the person recognized. What makes people autonomous and responsible seems to be more than the fact that we see them so. Does a person lack human dignity, if they are not recognized has possessing it? But if recognition perceives moral status, we must presuppose a conception of value realism that Honneth finds problematic, and it is not clear how much work the recognitive attitude does. Why is 
recognition of a person's dignity necessary, if they possess it regardless of it being recognized? In the end, Honneth opts for a version of the perception model:

In our recognitional attitudes, we respond appropriately to evaluative qualities that, by the standards of our lifeworld, human subjects already possess but are actually available to them only once they can identify with them as a result of experiencing the recognition of these qualities (Honneth 2002: 510).

This version of the perception model stresses the second-natural character of the attributes that we perceive and confirm in acts of recognition. Even though by the standards of our lifeworld humans are autonomous agents with moral responsibility, our acts of recognition, in affirming this fact, enable them to see themselves as such agents. This is in keeping with sociological insights. Even though the belief in human dignity is a cornerstone of Western modernity, people struggle to "live up" to it, to live dignified lives without forms of social recognition that public affirm their possession of dignity (Jütten [forthcoming]).

Turning to the three dimensions of recognition, Honneth's conception of love as a form of mutual recognition in the bourgeois family also poses challenges. Some critics have suggested that while he rejects the Rousseauian and Hegelian models of conjugal love as based on the complementarity of the male and female genders, The Struggle for Recognition does not have the resources to elaborate an alternative, egalitarian vision of conjugal love (Young 2007). Arguably, Freedom's Right addresses this problem. To be sure, Honneth argues that conjugal love is a form of social freedom in which the lovers supplement and complete each other, but this completion does not presuppose the natural complementarity envisaged by Rousseau and Hegel. Rather, in conjugal love, "each person is a condition for the freedom of the other by becoming a source of physical self-experience for the other; each person's natural being thus strips off its socially imposed constraints and recovers in the other a piece of his or her 
individual freedom" (Honneth 2014: 151). On this account, lovers complement each other, because their intimacy creates shared experiences in which both feel completed.

While love as a form of recognition (and social freedom) continues to attract critical attention (McNay 2015), the differentiation of legal respect and social esteem, and the transformation of social esteem in the capitalist recognition order have been the most innovative, but also the most controversial aspects of Honneth's theory of recognition.

\section{Social Esteem, Self-Realization, and Solidarity}

The concept of a capitalist recognition order does not appear in The Struggle for Recognition. Honneth introduces it in his first contribution to his exchange with Nancy Fraser, Redistribution or Recognition? However, much of its conceptual background first appears in the earlier work when Honneth discusses the transformation of social esteem during the transition from Feudalism to capitalism. Social esteem enables individuals to relate positively to their own traits and abilities. It is a is a form of recognition that affirms the socially defined worth of their individual characteristics, that is, particular qualities which differentiate individuals from others. These qualities are worthy of esteem to the extent that they enable individuals to contribute to socially shared goals or values. This presupposes socially shared background assumption about what these goals or values are, and these assumptions clearly will be historically variable (Honneth 1996: 122).

In particular, Honneth argues that in pre-modern estates-based societies such ethical goals and values are substantive and hierarchical. Society is stratified and assigns a different value to different social estates (e.g. the nobility, the clergy), corporations and guilds, according to their purported contribution to society and the specific style of life that characterizes 
membership of these estates. Individuals gain social esteem, which here is conceived of as honor, to the extent that they fulfil the functions of their estate and live up to the socially expected standards defined by their membership of that estate. Social recognition between members of a given estate, corporation or guild is symmetrical, while relationships of recognition between members of different status groups are asymmetrical. Esteem is graded according to the hierarchy of the groups (Honneth 1996:123). As a result, individuals are not esteemed as individuals but as members of their status group.

This system of recognition relations, which Honneth also calls corporative, comes under pressure when the cultural self-understanding of modernity begins to challenge the legitimacy of traditional hierarchies. This process splits traditional honor into three distinct valuations. First, legal respect becomes a separate form of social recognition and enshrines the equal moral standing of each individual in law. From now on, individuals are recognized as autonomous subjects, and this autonomy gives them their dignity as persons. Second, the aspect of honor that is concerned with personal conduct is privatized as subjectively defined "integrity." It plays no further role in Honneth's theory of recognition. Finally, social esteem comes to be the form of social recognition that bestows "prestige" or "standing" on individuals, and it becomes associated with their chosen form of self-realization through which they contribute to socially shared goals. Social status comes to track "achievement." However, as Honneth recognizes, the problem with a recognition order that accords social esteem on the basis of individual achievement is that it presupposes a shared conception of social goals and a shared horizon of values which can be used to judge what counts as a contribution. But it is precisely this shared self-understanding that modern societies lack in the absence of the substantive ethical selfunderstanding of traditional societies. Instead, modern societies are characterized by permanent cultural conflicts and struggles for recognition in which individuals fight for the recognition of 
their particular achievements as contributions to socially shared goals (Honneth 1996: 126). Still, esteem recognition in modern societies odes require some agreement about socially shared goals.

Honneth suggests that individual conceptions of self-realization come to take the place of a collective ethical self-understanding. The argument is that individuals contribute to socially shared goals through their individually chosen form of self-realization, and for that they are accorded social esteem (Honneth 1996: 126). Social worth is accorded to various forms of selfrealization, because modern societies recognize as worthy the particular ways in which individuals have chosen to live their lives. As a result, judgments about social esteem can be quite complex, because it is not always obvious or universally recognized that a particular form of self-realization contributes to socially shared goals. Moreover, individuals or social groups may engage in struggles for recognition in order to gain affirmation for their particular ways of life. In the case of successful struggles for recognition, the contribution of a particular form of self-realization to socially shared goals becomes recognized. At one point, Honneth gives the example of a "stay-at-home dad" in order to make this point. For a man to stay at home and raise his children only becomes a recognizable form of self-realization once it is no longer seen as a euphemism for unemployment and seen as a genuine contribution to socially shared goals (Anderson and Honneth 2005: 136). This example also reminds us that struggles for recognition often are necessary in order to break up traditional gendered norms about recognizable forms of self-realization.

Honneth characterizes the form of social recognition expressed through social esteem as one of solidarity. This is intuitively plausible in pre-modern estates-based societies, where individuals are accorded symmetrical social esteem by their peers on the basis of their common 
membership in an estate, corporation or guild and their shared value system. According to Honneth, in this context solidarity "can be understood as an interactive relationship in which subjects mutually sympathize with their various different ways of life because, among themselves, they esteem each other symmetrically" (Honneth 1996: 128). But how does solidarity arise in modern societies? Honneth's answer is that in the absence of a shared substantive self-understanding, solidarity will arise to the extent that individuals recognize each other as individually valuable in the joint pursuit of socially shared goals. This affirmation of individual value is a state of solidarity, because gives self-esteem to the individual who is recognized. According to Honneth,

Relationships of this sort can be said to be cases of 'solidarity', because they inspire not just passive tolerance but felt concern for what is individual and particular about the other person. For only to the degree to which I actively care for the development of the other's characteristics (which seem foreign to me) can our shared goals be realized. (Honneth 1996: 129)

Honneth wants to characterize this form of mutual recognition as symmetrical, too, although it seems clear that not every individual contributes equally to socially shared goals, and the value of any contribution is open to dispute. The symmetry of esteem recognition therefore consists in the fact that all individuals are free from collective denigration.

This is a puzzling claim, and it becomes more puzzling when Honneth adds that given the form of solidarity described in the quote above, "individual competition for social esteem can then acquire a form free from pain," because it is "not marred by experiences of disrespect" (Honneth 1996: 130). First, it is not clear what work the concept of solidarity does in Honneth's account of social esteem in modern societies, and second, it is not clear how Honneth conceives 
of the relationship between solidarity and competition. Let me expand on each of these two points in turn.

As we have seen, in estates-based societies, individuals are bound together by bonds of solidarity, because they share a value system and a broad style of life, perhaps based on the ethos of their corporation or guild, even though Honneth makes clear that individuals may pursue various different ways of life within in the confines their shared ethical selfunderstanding. The bonds in question are described appropriately as solidarity in the sense that they serve a unifying function that mediates between individual and society and ground positive duties between individuals (Scholz 2008: 18-20). In terms of Sally Scholz's helpful typology, the form of solidarity is described appropriately as social, because it is a form of mutual dependency based on social cohesion and shared consciousness and experience which issues in the positive duties of individuals to help and support each other in day-to-day life. In particular, drawing on Durkheim's famous distinction, it is a form of "mechanical" social solidarity in the sense that individuals are bound together by their similarity, rather than by their complementarity (Scholz 2008: 21-27).

In contrast, in modern societies, individuals may pursue radically different ways of life based on highly individualized conceptions of the good. Nevertheless, Honneth must assume that individuals share at least some social goals, and solidarity is based on the recognition that different individuals through their chosen form of self-realization contribute to these socially shared goals. Thus, while modern social solidarity has a much weaker affective basis, it has a basis in the recognition of limited but significant shared interests that bind members of society together and give them reasons to help and support each other. In terms of Scholz's typology, Honneth's modern social solidarity therefore sits somewhere between, a weaker form of social 
solidarity, which is "organic" rather than "mechanical," in that individuals are bound together by their complementarity, rather than their similarity, and "civic solidarity," which exists between members of a political state and protects individuals from vulnerabilities that would exclude them from participation in the civic public (Scholz 2008: 27). This form of solidarity is weaker, because instrumental and conditional. It is instrumental, because it establishes positive duties of help and support on the basis of mutual self-interest in the realization of socially shared values, rather than on affective ties and shared consciousness and experience, and therefore it is conditional on individuals being perceived as making a contribution to socially shared goals.

It seems that the role of solidarity has shifted in the transition from pre-modern to modern societies. In the former, solidarity seemed to be the expression of social esteem. To be esteemed is to be included in social relations of solidarity. Solidarity is a medium of social esteem. In the latter, solidarity seems to be the background against which social esteem is distributed and pursued. Therefore, in modern societies, solidarity does not seem to be a medium of social esteem. As we shall see in the next section, in modern societies money, and in particular income, becomes the primary medium of esteem.

This leads to the question of the relationship between solidarity and competition. Honneth suggests that the existence of this form of solidarity enables individuals in modern societies to compete for social esteem without fear of collective denigration. Solidarity expresses the socially shared conviction that individuals in society trough their chosen form of selfrealization typically do make a contribution to socially shared goals, even though they may do so to various degrees and with varying degrees of success. Against this background of "felt concern for what is individual and particular about the other person" (Honneth 1996:129), 
individuals will be motivated to pursue socially shared goals in order to gain the social esteem of their peers, and thereby maximize the realization of these goals. But this optimistic conception of esteem competition as a mechanism that maximizes the realization of socially shared goals as if by invisible hand seems to overlook that competition also can undermine solidarity and lead to status hierarchies that embody precisely the denigration of ways of life that the theory of recognition criticizes. One reason for this is that social status is a positional good. Once social esteem is gradated, so that some individuals or groups are more esteemed than others, individuals or groups can improve their position in the status order either by increasing their own social esteem or by decreasing that of their peers. In such a competitive environment, we have no good reason to believe that everybody will be satisfied with basic social recognition as a contributor to socially shared goals. As a result, there will be a very strong stratification of social esteem in society, and social solidarity will come under severe pressure. Honneth's analysis of the capitalist recognition order in Redistribution or Recognition? bears this out. For the concept of solidarity disappears from his analysis in that book.

\section{The Capitalist Recognition Order}

Honneth's analysis of modern capitalism as a recognition order is one of the greatest achievements of his theory of recognition. To conceptualise society as a recognition order is to consider it as a normative order that institutionalizes the distribution of respect and social esteem and therefore expresses the social valuations that most people in this society see as legitimate. It is the normative horizon against which specific struggles for recognition take place (Honneth 2003a: 148-49). This analysis is innovative, because it offers conceptual tools for the moral evaluation of market societies which depart from established debates about distributive justice in liberal political philosophy and argues that misrecognition underlies 
many of the injustices that individuals experience in the market economy. It is also a valuable addition to critical theories of capitalism in the Marxist tradition which analyze structures of oppression but do not have the conceptual tools to articulate how and why the oppressed experience their oppression as moral injury. However, Honneth's analysis of capitalism also has been criticized for failing to explain all forms of injustice that individuals experience. This section will trace Honneth's account of the emergence of the capitalist recognition order in some detail, before focusing on some of the criticisms. The next section will look at Nancy Fraser's criticism of Honneth in her contributions to Redistribution or Recognition?

Honneth begins with discussion in In Redistribution or Recognition? with a restatement of the history of the modern recognition order as the breaking up of the pre-modern "alloy of legal respect and social esteem - the moral fundament of all traditional societies" (Honneth 2003a: 140). Like in The Struggle for Recognition, but in much more detail, Honneth next focuses on the basis of social esteem in modern capitalist societies. As we have seen, the neutral term for this basis is "individual achievement" (Honneth 2003a: 140). In particular, the capitalist recognition order valorizes "individual achievement within the structure of the industrially organized division of labor" (Honneth 2003a: 140). Social esteem is accorded to individuals on the basis of their success as productive citizens, and the implication is that esteem therefore has been meritocratized (Honneth 2003a: 141), so that what matters now is ability, effort or success, rather than social status conferred on the basis of birth, caste or class, that is, characteristics that individuals cannot deserve or be responsible for.

As we have seen in our bird's eye view of Honneth's theory of recognition, his discussion of the capitalist recognition order in Redistribution or Recognition? aims to paint a realistic picture of modern capitalist societies. Honneth acknowledges that these societies were 
"hierarchically organized in an unambiguously ideological way from the start" (Honneth 2003a: 141). In terms of the recognition-theoretical framework this means that what counts as "achievement" was always already skewed in favor of the independent, male, middle-class bourgeois, and this ideological bias has survived until today. As a result, a specific model of individual achievement, "investment in intellectual preparation for a specific activity" (Honneth 2003a: 147), which is paradigmatically realized in entrepreneurship and the professions, still dominates the capitalist recognition order, while many other contributions to socially shared goals are under-valued. This includes manual and repetitive forms of labor performed by dependent working-class laborers and many forms of care and house work primarily performed by women.

To be sure, Honneth's discussion of the capitalist recognition order in Redistribution or Recognition? does not offer a justification of the ideology underpinning this order. Rather, it serves the twin aim of explaining the legitimacy of capitalism in the eyes of modern subjects and of showing that there are immanent resources in the capitalist recognition order that justify criticism of that order. According to Honneth, capitalism is not "norm-free", a position often ascribed to Habermas, but rather governed by normative principles, namely, principles of social recognition, even though the specific recognition principles and their application frequently are contested (Honneth 2003a: 142). Consider the labor market. People often appeal to the normative vocabulary of desert or merit in order to articulate their claims for better working conditions or better pay. But labour markets are complex social institutions in which "efficiency considerations... are inextricably fused with cultural views of the social world" (Honneth 2003a: 156), which determine the social value of a particular job or profession. Until recently, in modern capitalist societies labour markets were tightly regulated, and these regulations expressed these societies' understandings of desert and justice and of the specific 
vulnerabilities to which workers are exposed. These immanent norms go some way toward explaining why people see capitalism as legitimate, but they also explain why people feel justified in criticizing it when it falls short of its immanent promise, the surplus of validity that all norms contain (Honneth 2003a: 186).

This account of the capitalist recognition order suggests that struggles for recognition in the sphere of social esteem which appeal to social solidarity, including struggles for socialwelfare benefits for the unemployed, but also for better working conditions, can be transformed into struggles about social rights, so that unemployment benefits and decent working conditions are no longer seen as expressions of esteem for the social contribution of workers but of respect for their equal rights (Honneth 2003a: 149). In fact, Honneth conceives of this boundary-shifting between recognition spheres as a form of moral progress, because it decouples social rights from the need for justification in terms of individual achievement (Honneth 2003a: 188). This seems right, because the legal guarantee of social-welfare entitlements establishes the social minimum as something that one is due as everyone's equal, rather than as a social inferior. However, Honneth also notes that the demonization of the unemployed as skivers and the attempts to curtail their social rights are obvious examples of the erosion of respect based on a prior erosion of social esteem. The "social stigma" (Honneth 2010b:224) of unemployment cuts across respect and esteem recognition. Once a class of individuals is characterised as useless and replaceable and therefore not worthy of social esteem, their ability to exact the equal respect that is due to them as citizens in the form of social rights is undermined, too (Honneth and Stahl 2013: 283).

This points to an important insight of Honneth's theory of recognition. Once social esteem becomes a necessary condition for individual self-realization, the ability to be recognized as 
making a contribution to socially shared goals, in other words, the ability to be recognized as useful to others, becomes of the upmost importance. In the capitalist recognition order, most individuals demonstrate their usefulness through work, organized in the social division of labor. But not everyone can or does make a contribution to socially shared goals, and not everyone can develop such ability to the same degree. As a result, the capitalist recognition order issues in a social status order in which social esteem is unequally distributed between people. This would be true, even if this order were to track genuine social contributions and to reward genuine achievements. In reality, where the capitalist recognition order is ideologically distorted and one-sided, the distribution of social esteem reproduces and legitimizes the existing hierarchies of social class and prestige. And in such a hierarchical class society, many struggle to establish their worth in the eyes of others, as it becomes comparative and positional in nature.

\section{Fraser's Criticism}

In her contributions to Redistribution or Recognition? Nancy Fraser puts forward a number of objections of Honneth's conception the capitalist recognition order (Fraser 2003a; Fraser 2003b). Perhaps the most influential objection is directed at Honneth's "monism," that is, his view that struggles for redistribution can be reduced to struggles for recognition. Fraser uses the example of an industrial worker who loses his job because of an industrial merger (Fraser 2003a: 35). The loss of his job cannot be explained meaningfully by a re-evaluation of his achievement or contribution to socially shared goals. Rather, it must be explained by reference to political-economic factors that operate at the systemic level of the market economy and are governed by profitability considerations (Fraser 2003b: 215). The upshot of this example is that there is an entire dimension of capitalism that the theory of recognition does not capture, and therefore the recognition-theoretical analysis of capitalism is incomplete. Fraser's 
alternative is an explanatory dualism, according to which individuals can suffer from maldistribution, misrecognition, or both, and neither can be reduced to the other (Fraser 2003a: 34-37).

In response, Honneth could suggest a "weak" reading of his argument (Zurn 2015: 140), according to which the capitalist recognition order is one of several causal determinants of market outcomes, which derives its force from the fact that the functioning of the market has recognitional preconditions. The market depends on laws, social norms, psychological dispositions and particular self-relationships of actors which could be withdrawn if people no longer believed that the market is a legitimate sphere of social recognition. The problem with this weak version of the argument may be that it is too abstract to offer explanations of specific economic problems or guide emancipatory politics (Zurn 2015: 145).

For better or for worse, Honneth seems to move in the direction of a weaker argument, which stresses the fact that economic action is embedded in a moral framework. In his most recent discussion of the market economy in Freedom's Right, Honneth returns to the language of solidarity in order to make this point:

[T]he market can only fulfill its function of harmoniously integrating individual economic activities in an unforced manner and by means of contractual relations if it is embedded in feelings of solidarity that precede all contracts and obligate economic actors to treat each other fairly and justly. (Honneth 2014: 181)

Of course, it remains unclear what exactly the relationship is between solidarity, fairness, and justice on the one hand, and individual economic action, which is self-interested by definition (although it may include a concern for others' welfare), on the other. If it turns out that fairness and justice are compatible with the economic choices that have put Fraser's industrial worker 
out of a job, then the solidarity underpinning these norms must be very weak. Otherwise, we would expect such job losses to be accompanied by very substantial forms of compensation, redeployment or retraining, which would reassure the workers of their continued worth in the eyes of their fellow citizens. But if it turns out that fairness and justice are incompatible with it, then we have strong reasons to believe that solidarity, fairness and justice, in fact, are not immanent norms of the market economy (Jütten 2015). To be sure, some norms of fairness and justice may be operative in market economies, because they are demanded by respect for the autonomy and dignity of individuals, but they are not based on the solidarity that individuals owe to each other, because they recognize each other as making a contribution to socially shared goals.

\section{Conclusion: Looking Forward}

Honneth's theory of recognition offers a unique perspective on modern capitalist societies. Its focus on mutual recognition as a necessary condition of individual self-realization reveals forms of disrespect and humiliation to be deeply political phenomena that form the experiential basis of social struggles for recognition and resistance against many forms of material and symbolic domination. At the same time, as we have seen, some basic questions about the explanatory power of recognition remain contested, especially in the sphere of the market economy. At the same time, Honneth has taken the lead in using the recognition-theoretical framework in order to offer re-interpretations of both philosophical concepts and social phenomena. For example, he has developed a recognition-theoretical re-conception of ideology (Honneth 2007b) and an account of the decline of normative conceptions of work and the labor market (Honneth 2010b). It would be interesting to see the theory of recognition used in other areas of social and political thought. 
One obvious area for development is Feminist philosophy. As we have seen, Honneth has been very interested in gender from the beginning, and his treatment of love and the family has led to many debates among and with Feminists. The question of whether Feminists ought to advocate the recognition of childcare and housework as work that should be recognized through payment, is a good example of this (Rössler 2007). However, there are other questions in Feminist philosophy which may profit from a recognition-theoretical perspective. For example, sexual objectification could be analyzed fruitfully as a form of ideological recognition or misrecognition. Likewise, more work could be done on the persistent "hidden injuries of class" (Sennett and Cobb 1972) that manifest themselves as a lack of social recognition (Jütten [forthcoming]). One expected pay-off of such work would be the further conceptual specification of the phenomenon of misrecognition through its application to specific social issues. It is a strength of the recognition-theoretical approach that it is able to disclose forms of social suffering that are difficult to capture in the language used by liberal theories of justice. The enduring legacy of this latest shift in Frankfurt School critical theory will depend on whether there is uptake for the concepts that it adds to the toolbox of social criticism.

[6,840 words]

\section{Related Topics}

The Idea of Immanent Criticism

The Idea of Political Economy

Critical Theory and Social Pathology

Critical Theory and Contemporary Politics

Critical Theory, Developments and Future Prospects

Critical Theory and Feminism

\section{References}


Anderson, J. and Honneth, A. (2005) "Autonomy, Vulnerability, Recognition, and Justice," in J. Christman and J. Anderson (eds), Autonomy and the Challenges to Liberalism, Cambridge: Cambridge University Press.

Fraser, N. (2003a) "Social Justice in the Age of Identity Politics: Redistribution, Recognition, and Participation," in: N. Fraser and A. Honneth, Redistribution or Recognition? A Political-Philosophical Exchange, London: Verso.

---- (2003b) "Distorted Beyond All Recognition: A Rejoinder to Axel Honneth," in: N. Fraser and A. Honneth, Redistribution or Recognition? A Political-Philosophical Exchange, London: Verso.

Fraser N. and Honneth A. (2003) Redistribution or Recognition? A Political-Philosophical Exchange, London: Verso.

Honneth A. (1996 [1992]), The Struggle for Recognition: The Moral Grammar of Social Conflicts, Cambridge MA: The MIT Press.

- (2002) "Grounding Recognition: A Rejoinder to Critical Questions," Inquiry 45(4): 499_ 519.

----- (2003a) "Redistribution as Recognition: A Response to Nancy Fraser," in: N. Fraser and A. Honneth, Redistribution or Recognition? A Political-Philosophical Exchange, London: Verso.

---- (2003b) "The Point of Recognition: A Rejoinder to the Rejoinder," in: N. Fraser and A. Honneth, Redistribution or Recognition? A Political-Philosophical Exchange, London: Verso.

---- (2005) Reification. A New Look at an Old Idea, New York: Oxford University Press.

---- (2007a) "Pathologies of the Social: The Past and Present of Social Philosophy," in Axel Honneth, Disrespect. The Normative Foundations of Critical Theory, Cambridge: Polity.

---- (2007b) "Recognition as Ideology," in B. van den Brink and D. Owen (eds), Recognition and Power: Axel Honneth and the Tradition of Critical Social Theory, Cambridge: Cambridge University Press.

----- (2008) Reification. A New Look at an Old Idea, ed. Martin Jay. Oxford and New York: Oxford University Press.

---- (2010a) The Pathologies of Individual Freedom. Hegel's Social Theory, Princeton NJ: Princeton University Press.

---- (2010b) "Work and Recognition: A Redefinition," in H.-C. Schmidt-am-Busch and C. Zurn (eds), The Philosophy of Recognition, Lanham MD: Lexington Books.

---- (2014) Freedom's Right. The Social Foundations of Democratic Life, Cambridge: Polity. Honneth, A. and Stahl, T. (2013) "Wandel der Anerkennung: Überlegungen aus gerechtigkeitstheoretischer Perspektive," in A. Honneth et al. (eds), Strukturwandel der Anerkennung: Paradoxien sozialer Integration in der Gegenwart, Frankfurt and New York: Campus.

Ikäheimo, H. (2002) "On the Genus and Species of Recognition," Inquiry 45(4): 447-62.

Jütten, T. (2015) "Is the Market a Sphere of Social Freedom?" Critical Horizons 16(2): 187203.

----- (forthcoming) "Dignity, Esteem and Social Contribution: A Recognition-Theoretical Perspective," Journal of Political Philosophy.

Laitinen, A. (2002) "Interpersonal Recognition: A Response to Value or a Precondition of Personhood?" Inquiry 45(4): 463-78.

McNay, L. (2015) "Social Freedom and Progress in the Family: Reflections on Care, Gender and Inequality," Critical Horizons 16(2): 170-86.

Petherbridge, D. (2013) The Critical Theory of Axel Honneth, Lanham MD: Lexington Books. 
Rössler, B. (2007) "Work, Recognition, Emancipation," in B. van den Brink and D. Owen (eds), Recognition and Power: Axel Honneth and the Tradition of Critical Social Theory, Cambridge: Cambridge University Press.

Scholz, S. (2008) Political Solidarity, State College PA: Pennsylvania State University Press.

Sennett, R. and Cobb, J. (1972) The Hidden Injuries of Class, Cambridge: Cambridge University Press.

Young, I.M. (2007) "Recognition of Love's Labor: Considering Axel Honneth's Feminism," in B. van den Brink and D. Owen (eds), Recognition and Power: Axel Honneth and the Tradition of Critical Social Theory, Cambridge: Cambridge University Press.

Zurn, C. (2000) "Anthropology and Normativity: A Critique of Axel Honneth's 'Formal Conception of Ethical Life'," Philosophy and Social Criticism 26(1): 115-24.

----- (2015) Axel Honneth, Cambridge: Polity.

\section{Further Reading}

Fraser N. and Honneth A. (2003) Redistribution or Recognition? A Political-Philosophical Exchange, London: Verso. This famous debate between Fraser and Honneth is the quickest introduction to the discussion about recognition in critical social theory.

Honneth A. (1996 [1992]), The Struggle for Recognition: The Moral Grammar of Social Conflicts, Cambridge MA: The MIT Press. The original statement of Honneth's theory of recognition.

Zurn, C. (2015) Axel Honneth, Cambridge: Polity. The best introduction to and overview of Honneth's theory of recognition. 